\title{
Upaya Dinas Kebudayaan Dan Pariwisata Mempromosikan Mesjid Raya Pulau Penyengat Sebagai Daerah Tujuan Wisata di Tanjung Pinang Kepulauan Riau
}

\author{
SEFRONA SYAIFUL \\ $\&$ \\ ACHMAD SYECH MR \\ Dosen tetap Sekolah Tinggi Pariwisata Riau
}

\begin{abstract}
Efforts to make the Masjid Raya Island Biting as an object of religious tourism in the province of Riau Islands, has been carried out by the manager and local governments, among others, the promotion to both domestic and international travelers is done so that the level of tourists who come can be as expected, Promotional efforts undertaken by the Department of Culture and Tourism in increasing the number of visits such as: the availability of tourism information center, stinger island festival, held in cooperation with travel agencies and increased advertising on the island stinger. And the presence of Culture and Tourism today can say is good. With various promotions conducted by the relevant authorities so that the future can increase traffic. The potential for developing tourism on the island Biting the moment is religious tourism and historical tourism and culture
\end{abstract}

Keywords: Promotion, Mesjid Raya, Religious Tourism

\section{PENDAHULUAN}

Provinsi Kepulauan Riau merupakan salah satu daerah tujuan wisata di Indonesia yang mempunyai objek-objek wisata yang cukup potensial untuk dikembangkan. Mulai diberlakukannya otonomi daerah oleh pemerintah pusat pada awal tahun 1998, membuat pemerintah provinsi Kepulauan Riau semakin gencar melakukan pembangunan di berbagai sektor, termasuk sektor pariwisata.

Pariwisata merupakan salah satu alternatif dalam meningkatkan ekonomi di Provinsi Kepulauan Riau, karena dengan mengembangkan sektor ini diharapkan banyak wisatawan yang berkunjung ke Kepulauan Riau yang dengan sendirinya akan membawa devisa untuk dibelanjakan di negeri ini dengan mengupayakan pengembangan dan pemanfaatan potensi wisata yang dimiliki daerah dalam wujud kekayaan alam yang indah, keragaman flora dan fauna, kemajemukan tradisi dan seni budaya serta peninggalan sejarah dan purbakala.

Melanjutkan prospek segitiga SIJORI yang cerah, pulau-pulau di Propinsi Kepulauan Riau terutama Pulau Batam, Pulau Rempang, dan Pulau Galang Tengah digarap untuk dihubungkan dengan jembatan menjadi satu kawasan BARELANG. Kawasan ini memperluas pengembangan Batam yang telah hampir mendekati Batas daya serap instansi di pulau tersebut. Berbagai industri di Provinsi Kepulauan Riau seperti antara lain industri pengolahan hasil hutan dan industri hasil pertanian, yang meliputi minyak sawit, rotan, kayu lapis, crumb rubber, udang beku, ataupun industri dengan kadar ilmu pengetahuan dan teknologi tinggi, seperti industri pertambangan minyak dan gas bumi, industri perkapalan, industri mesin-mesin, dan manufaktur, berpotensi untuk dikembangkan. 
Pengembangan industri yang menggunakan teknologi madya dan tinggi tersebut dapat melibatkan serta memanfaatkan kehadiran perusahaan-perusahaan transnasional yang ada di provinsi ini. Keputusan Menteri Dalam Negeri Nomor : 130-67 Tahun 2002 tentang pengakuan kewenangan Kabupaten/Kota Provinsi menyangkut tentang kepariwisataan disebutkan bahwa masalah pengaturan dan pengelolaan objek dan daya tarik wisata serta penetapan inventarisasi potensi objek dan kawasan wisata merupakan kewenangan pemerintah daerah Kota/Kabupaten. Selaras dengan keputusan ini maka semua kota melalui Dinas Pariwisata, Kebudayaan, Pemuda dan Olahraga melakukan investarisasi potensi objek wisata dan kawasan wisata yang ada di setiap kota dan kabupaten.

Salah satu kota di Provinsi Kepulauan Riau yang sedang berkembang adalah kota Tanjung Pinang. Di kota Tanjung pinang terdapat berbagai macam objek wisata seperti wisata religi, wisata sejarah, wisata budaya, wisata kuliner, agro wisata dan sarana wisata. Hal ini membuat pemerintah provinsi Kepulauan Riau melalui dinas-dinas terkait dan investor bisnis pariwisata memikirkan alternatif lain di bidang pariwisata yaitu menjadikan Provinsi Kepulauan Riau sebagai kota bisnis wisata di pulau Sumatera. Guna mendukung semua itu pemerintah provinsi Kepulauan Riau bekerja sama dengan para investor membangun sarana-sarana yang mendukung kegiatan kepariwisataan tersebut, seperti perbaikan sarana prasarana dilokasi daerah tujuan wisata seperti hotel-hotel berbintang bertaraf internasional serta bermacam - macam pusat pembelanjaan.

Dimana dalam konteks wilayah kota Tanjung Pinang memiliki sebuah pulau yaitu Pulau Penyengat. Pulau Penyengat ini terletak di sebelah barat kota Tanjung Pinang. Secara astronomi Pulau Penyengat terletak pada $\mathrm{O}^{0} 56^{\prime} \mathrm{LU}$ dan $104^{0} 29^{\prime} \mathrm{BT}$ dengan panjang $2 \mathrm{~km}$, lebar $1 \mathrm{~km}$. Pulau Penyengat ini sering disebut dengan istilah Pulau Maskawin karena pulau ini merupakan Maskawin Sultan Mahmudsyah untuk Engku Puteri Raja Hamidah. Pulau Penyengat dikenal dengan nama Pulau Penyengat Indra Sakti.

Dari sekian banyak objek wisata di kota Tanjung Pinang, yang paling memliki nilai sejarah dan keunikan tersendiri adalah Mesjid Raya Pulau Penyengat, untuk mengunjungi objek wisata Masjid Raya Pulau Penyengat, hanya memerlukan waktu sekitar 30 menit dari pusat kota dengan menggunakan kendaraan umum, atau kendaraan pribadi dan dilanjutkan dengan perahu motor kecil (kapal pompong) karena objek tersebut ada di seberang Pulau Tanjung Pinang, objek wisata ini biasanya ramai dikunjungi pada saat akhir pekan atau hari libur. Wisatawan yang datang pun beragam, baik yang dari dalam provinsi Kepulauan Riau sendiri maupun dari luar provinsi Kepulauan Riau. Dalam hal jumlah pengunjung, dapat dikatakan setiap hari pasti ada pengunjung tetapi tidak seperti yang diharapkan oleh pihak pengelola maupun dari pihak pemerintah selaku pembina sarana dan prasarana kepariwisataan namun untuk beribadah sholat tetap berjalan seperti biasanya.

Berbagai upaya untuk menjadikan Masjid Raya Pulau Penyengat sebagai objek wisata religi di provinsi Kepulauan Riau, telah dilakukan oleh pihak pengelola dan pemerintah daerah antara lain melakukan promosi baik kepada wisatawan domestik maupun wisatawan internasional ini dilakukan agar tingkat kunjungan wisatawan yang datang dapat seperti yang diharapkan. Rata-rata tingkat kunjungan wisatawan yang datang ke Mesjid Raya Pulau penyengat yang mana tingkat kunjungan terus mengalami penurunan. Hal ini dikarenakan kurangnya promosi serta kurangnya fasilitas sarana dan prasarana yang dibangun di kawasan Mesjid raya tersebut. Dalam hal ini sangat dituntut upaya dari pemerintah setempat khususnya Dinas Kebudayaan dan Pariwisata untuk meningkatkan lagi kunjungan wisatawan. Berbagai upaya untuk menjadikan Masjid Raya Pulau Penyengat sebagai objek wisata unggulan di 
Provinsi Kepulauan Riau, telah dilakukan oleh pihak pengelola antara lain melakukan promosi baik kepada wisatawan domestik maupun wisatawan internasional. Bermacam promosi yang dilakukan adalah dengan mengadakan iklan di media cetak dan media elektronik.

Berdasarkan uraian yang dikemukakan di atas, maka penulis tertarik untuk menjadikan Masjid Raya Pulau Penyengat sebagai tempat penelitian dengan pertimbangan sebagai berikut : Masjid Raya Pulau Penyengat memiliki potensi untuk dijadikan sebagai objek wisata religi yang siap dikunjungi. Adanya kawasan pendukung di sekitar mesjid yang dapat dikunjungi oleh wisatawan namun belum tertata dengan baik. Masjid Raya Pulau Penyengat mudah terjangkau untuk dikunjungi baik dari provinsi Kepulauan Riau maupun luar daerah provinsi Kepulauan Riau. Mesjid Raya Pulau Penyengat merupakan bukti sejarah agama Islam masuk ke provinsi Kepulauan Riau.

Sebagai kerangka pemikiran di dalam penulisan perlu adanya landasan-landasan teori yang mendukung penelitian ini. Sesuai dengan uraian yang lainnya, berikut ini penulis akan mengemukakan beberapa teori yang ada hubungannya dengan masalah yang dibahas. Menurut Himawan Kartajaya, (2009: 10) strategi adalah konsep pemasaran diantaranya mencakup positioning, segmentasi dan targeting. Strategi dalam pariwisata mencakup yang ditawarkan oleh DTW (Daerah Tujuan Wisata) kepada wisatawan yang real maupun yang potensial. Penawaran dalam pariwisata menunjukkan khasanah atraksi wisata alamiah dan buatan manusia, jasa-jasa maupun barang-barang yang kira-kira akan menarik orang-orang untuk mengunjungi suatu Negara tertentu. Menurut Oka A. Yoeti, (2006:237) yang mengutip pendapat Kotler yang memperkenalkan bauran pemasaran dalam strategi untuk meningkatkan penjualan paket wisata melalui empat-P, yaitu product, price, place dan promotion.

Promosi adalah suatu upaya yang dilakukan untuk menyesuaikan produk pariwisata dengan permintaan wisatawan sehingga produk menjadi lebih menarik. (Happy Marpaung, 2002:103). Menurut Philip Kotler (2000: 265) mendefinisikan Marketing sebagai suatu proses sosial dan manajerial dan melalui proses tersebut individu dan kelompok memperoleh apa yang mereka butuhkan serta inginkan lewat penciptaan dan pertukaran timbal balik produk-produk dan nilai dengan orang lain. Sementara menurut masyarakat umum pemasaran hanya merupakan penjualan dan periklanan seperti melalui surat kabar, televisi, selebaran, dan lain sebagainya.

Promosi merupakan salah satu variabel yang dipakai untuk mempengaruhi pasar bagi suatu produk maupun jasa dari suatu perusahaan. Banyak yang berpendapat bahwa promosi itu sama dengan penjualan, Kegiatan promosi dalam prakteknya menurut Basu Swastha (1995 : 278) adalah sebagai alat untuk : Modifikasi tingkah laku, Orang-orang yang melakukan komunikasi itu mempunyai beberapa alasan, antara lain mencari kesenangan, mencari bantuan, memberi pertolongan atau instruksi, pengembangan ide dan pendapat. Sedangkan promosi dari segi lain berusaha merubah sikap tingkah laku dan pendapat, serta memperkuat sikap dan tingkah laku yang telah ada. Penjual sebagai sumber selalu berusaha menciptakan kesan yang baik yang ada pada dirinya (lembaganya) untuk mendorong peningkatan pembelian barang dan jasa yang ditawarkan. Pemberitahuan, kegiatan promosi dapat ditujukan untuk memberitahu pasar yang dituju tentang penawaran hasil produk suatu perusahaan. Promosi yang bersifat informasi ini harus dilakukan sejak tahap-tahap awal dari siklus kehidupan produk. Sebagian konsumen tidak akan membeli suatu produk, apabila mereka belum mengetahui apa bentuk produk tadi dan apa faedahnya produk tadi.

Promosi yang bersifat informative ini sangat penting dilaksanakan, karena akan sangat terkesan membantu untuk membeli atau tidak membeli. Membujuk, Promosi yang bersifat membujuk (persuasif) umumnya kurang disenangi oleh sebagian masyarakat. Namun 
kenyataannya dewasa ini promosi yang bersifat persuasif ini malah tumbuh dan berkembang, karena hasinya sangat menguntungkan. Promosi ini terutama ditujukan untuk menigkatkan jumlah pembelian dari suatu produk yang telah mulai memasuki tahap pertumbuhan dalam siklus kehidupannya. Mengingatkan, promosi yang bersifat mengingatkan dilakukan terutama untuk mempertahankan merk suatu produk agar tetap diminati oleh para konsumen. Promosi macam ini sangat perlu dilakukan apabila produk tadi telah memasuki tahap kedewasaan dalam siklus kehidupannya.

Menurut Salah Wahab ( 1992 : 158 ) Tujuan publikasi dan promosi adalah: publikasi terutama berkaitan dengan calon pembeli yang masih belum dikenal. Promosi terutama diarahkan pada calon pembeli yang sudah dikenal atau diketahui secara pribadi. Pada setiap bidang tugas ini ada 3 tujuan yang harus di cakup : Memperkenalkan produk wisata seluas mungkin. Menyusun produk itu agar sedapat mungkin menarik. Dengan demikian mendorong sebanyak mungkin orang, yang sudah mengenal produk wisata itu, untuk mencobanya. Menyampaikan isi pesan yang menarik, tanpa harus berbohong.

Oka A. Yoeti (2006:292) menyebutkan bahwa tujuan sales promotion yang penting adalah: Memperkenalkan produk baru; Meningkatkan frekuensi pemakaian; Menembah persediaan agen sebagai distributor; Menarik pelanggan baru; Counter terhadap aktivitas promosi yang dilakukan para pesaing; Mengaktifkan penjualan diwaktu sepi; dan Membantu kelancaran tugas sales executive melakukan pendekatan kepada pelanggan. Menurut Basu Swastha (2002: 214) pemasaran adalah suatu system keseluruhan dari kegiatan usaha yang dirancang untuk merencanakan, menetapkan harga, mempromosikan dan mendistribusikan barang, jasa dan ideide yang dapat memuaskan keinginan pasar sasaran dalam usaha mencapai tujuan organisasi.

Dan menurut Philip Kotler (2000:378) pengertian bauran pemasaran (Marketing Mix) adalah kombinasi dari empat variabel atau kegiatan yang merupakan inti dari system pemasaran yakni produk, struktur harga, system distribusi dan kegiatan promosi. Keempat unsur yang terdapat dalam kombinasi tersebut saling berhubungan dan saling mempengaruhi. Setiap variabel yang ada masing-masing mempunyai banyak sekali sub variabel, dengan demikian manajer harus dapat memilih kombinasi terbaik sehingga didapat ramuan yang sesuai dengan kondisi lingkungan.

Kotler secara ringkas menguraikan masing-masing variabel marketing mix sebagai berikut : Product (Produk): barang dan atau jasa yang ditawarkan di pasar untuk dikonsumsi oleh konsumen. Pengolahan produk termasuk di dalamnya perencanaan dan pengembangan produk dan atau jasa yang baik untuk dapat dipasarkan oleh perusahaan. Beberapa elemen dari produk tadi antara lain ialah kualitas, bentuk fisik, kemasan, merk dagang, servis, dan lain-lain. Price (harga): harga menduduki tempat yang penting karena akan menentukan penerimaan perusahaan. Dalam menentukan harus menitikberatkan pada kemampuan pembeli pada harga yang telah ditetapkan. Harga bukan semata-mata untuk menutupi biaya produk dan keuntungan yang diinginkan perusahaan, tetapi yang lebih penting akan menunjukkan persepsi konsumen terhadap suatu produk. Place (distribusi); merupakan upaya agar produk yang ditawarkan berada pada tempat dan waktu yang tepat sesuai dengan kebutuhan konsumen dengan biaya wajar.

Dalam pemasaran, yang merupakan suatu proses yang berlanjut. Adanya promosi dapat membantu pihak-pihak yang terlibat dalam pemasaran untuk memperbaiki hubungan antara pemasar dan konsumen. Variable lain disamping keempat variable marketing mix tersebut diatas sesuai dengan tugas dan fungsi perusahaan daerah dalam melaksanakan bauran pemasaran masih dikenal satu variable, yakni variable pelayanan (service). Variable ini sangat penting karena tanpa pelayanan yang baik konsumen tidak akan merasa puas. 
Promosi menurut R. S. Damardjati (2001:12) yang mempunyai Badan Promosi Pariwisata Indonesia (BPPI) adalah organisasi non pemerintah yang bertujuan untuk meningkatkan promosi pariwisata Indonesia di luar negeri. Para petugas BPPI ini rata-rata terdiri penguasa/pengusaha swasta yang bergerak dibidang pariwisata ataupun produk-produk jasa lain yang secara langsung maupun tidak langsung. Banyak pengertian tentang promosi yang dikemukakan oleh para ahli keanekaragaman tentang rumusan promosi tersebut antara lain, menurut Philip Kotler (2001:74) yang mendefenisikan promosi sebagai kreatifitas mengkomunikasikan keunggulan produk serta membujuk pelanggan sasaran untuk membelinya.

\section{METODE}

Jenis penelitian deskriptif, dengan menggunakan sampel Kepala Dinas, staff yang ada di Dinas Kebudayaan dan Pariwisata khususnya Divisi Pengembangan Kepariwisataan, pengurus Mesjid Raya dan wisatawan yang datang ke kawasan Mesjid Raya Pulau Penyengat. Data yang diperoleh dari hasil observasi dan wawancara dipilah-pilah dan diklasifikasikan menurut jenisnya dan kemudian dianalisis serta diolah dengan menggunakan metode tabulasi terhadap data yang terkumpul, kemudian melakukan analisis untuk mendapatkan gambaran dan disimpulkan secara nyata yang sesuai dengan tujuan penelitian ini.

\section{HASIL}

\section{Upaya promosi yang dilakukan dalam meningkatkan kunjungan wisatawan ke kawasan Mesjid Raya di Pulau Penyengat oleh Dinas Kebudayaan dan Pariwisata di Tanjung Pinang}

Sektor pariwisata pada saat ini merupakan sumber penerimaan negara yang paling diandalkan setelah penerimaan negara dari sektor minyak bumi dan gas alam merosot. Sehubungan dengan hal ini upaya peningkatan pembangunan sektor pariwisata sangat diperlukan. Sebagaimana yang tercantum dalam GBHN dinyatakan mengembangkan dan mendayagunakan sumber dan potensi kepariwisataan nasional menjadi kegiatan yang diandalkan untuk memperbesar penerimaan devisa, memperluas dan memeratakan kesempatan berusaha dan lapangan kerja terutama bagi masyarakat setempat, mendorong pembangunan daerah dan memperkenalkan alam budaya bangsa.

Promosi daerah tujuan wisata merupakan salah satu faktor yang sangat menentukan dan menjadi bagian penting bagi pengembangan pariwisata suatu kota. Promosi wisata di Kota Tanjung Pinang khususnya Pulau Penyengat sangat gencar dilakukan oleh Dinas Kebudayaan dan Pariwisata Kota Tanjung Pinang. Mengingat dunia pariwisata merupakan produk unggulan dan penyumbang terbanyak dari pendapatan asli daerah (PAD) Kota Tanjung Pinang, maka kegiatan promosi pariwisata Kota Tanjung Pinang masuk dalam agenda kerja dari Pemerintah Kota Tanjung Pinang. Selain dari Pemerintah Kota Tanjung Pinang, kegiatan promosi wisata juga dilakukan para pengelola usaha pariwisata seperti: hotel, restoran dan pengelola objek wisata.

Mesjid Raya Pulau Penyengat merupakan salah satu andalan dalam mendukung wisata religi, sejarah dan budaya di Provinsi Kepulauan Riau mengingat banyaknya peninggalan situssitus di pulau ini yang bisa menjadi objek unggulan bagi wisatawan domestik dan wisatawan 
internasional. Maka ada beberapa upaya yang dilakukan oleh Dinas Kebudayaan dan Pariwisata Tanjung Pinang dalam mempromosikan Pulau Penyengat yaitu:

1. Disediakannya Pusat Informasi Pariwisata

Sejauh ini kegiatan promosi wisata yang dilakukan di Kota Tanjung Pinang baru terbatas pada penyediaan informasi berupa brosur, stiker dan pamflet yang disebarluaskan di lokasi masing-masing objek wisata. Pelaksanaan promosi wisata seperti ini tentu saja belum efektif karena terbatas pada masing-masing objek wisata dan belum menggambarkan potensi wisata secara keseluruhan. Pusat promosi wisata di Kota Tanjung Pinang yang dikelola oleh Pemerintah Kota Tanjung Pinang yang bernama Pusat Informasi Pariwisata yang lokasinya terletak di Jalan Merdeka serta berdampingan dengan Kantor Dinas Kebudayaan dan Pariwisata Kota Tanjung Pinang. Bahwa masih ada kesempatan bagi Dinas Kebudayaan dan Pariwisata kota Tanjung Pinang untuk meningkatkan promosi pariwisata Pulau Penyengat tidak hanya sebatas brosur, stiker dan pamflet yang di sebar dilokasi objek wisata dan di tempatkan di pusat informasi pariwisata. Dengan tersedianya pusat informasi yang baik diharapkan wisatawan dapat lebih mengetahui dengan cepat dan akurat mengenai kawasan objek wisata di Tanjung Pinang khususnya Pulau Penyengat.

2. Diadakannya Festival Pulau Penyengat

Festival yang digagas Kementerian Pariwisata dan Ekonomi Kreatif ini bisa menjadi momentum untuk mempromosikan Penyengat sebagai pusat kebudayaan dan bahasa Melayu di Indonesia. Acara Festival Pulau Penyengat ini di selenggarakan setiap akhir tahun. Salah satu alasan menyelenggarakan Festival Pulau Penyengat ini adalah karena keunikan pulau tersebut atas berbagai peninggalan sejarah peradaban Melayu pada masa kerajaan Riau - Lingga. Kementerian menargetkan pada 2012, festival ini diselenggarakan lebih besar lagi dengan melibatkan peserta dari negara tetangga seperti Singapura dan Malaysia yang juga memiliki sejarah Melayu. Kegiatannya pun dibuat lebih banyak sehingga turis dari daerah lain bisa turut hadir menyemarakkan suasana.

Untuk mendukung rencana tersebut, pemerintah provinsi Kepulauan Riau telah mengagendakan serangkaian pembangunan infrastruktur pendukung di Penyengat seperti penyediaan listrik, air bersih dan jalan akses menuju situs sejarah. Perumahan di pinggir laut akan direhabilitasi agar terlihat lebih semarak dari kejauhan. Dan akan membuat Penyengat lebih terang benderang pada malam hari. Pemerinta provinsi juga akan merehabilitasi beberapa situs yang sudah rusak agar semakin menarik para pelancong yang berkunjung ke pulau tersebut. Rasanya tidak berlebihan jika perintah provinsi Kepulauan Riau berharap Penyengat bisa menyedot wisatawan yang ingin menyaksikan bukti sejarah kebesaran kerajaan Melayu di Kepulauan Riau.

Festival Pulau Penyengat sangat baik untuk dilaksanakan apabila didukung semua pihak terkait baik Dinas Kebudayaan dan Pariwisata kota Tanjung Pinang dan masyarakat pulau penyengat sendiri. Karena dengn kerjasama yang baik tersebut festival Pulau Penyengat akan menjadi sarana promosi secara langsung kepada wisatawan dalam dan luar negeri yang berkunjung pada saat festival tersebut diadakannya festival ini maka akan banyak orang yang mengetahui tentang kota Tanjung Pinang khususnya pulau Penyengat sehingga akan banyak mendatangkan wisatawan nusantara dan wisatawan mancanegara.

3. Diadakannya Kerjasama dengan Travel Biro 
Dapat diketahui bahwa travel biro memiliki peran yang strategis dalam mengembangan pariwisata kota Tanjung Pinang khususnya Pulau Penyengat. Dalam rangka pembangunan kota Tanjung Pinang di sektor pariwisata diperlukan keterlibatan biro perjalanan untuk menentukan pasar wisata yang tepat agar dapat dicapai hasil yang optimal. Dengan melihat peran travel biro yang dominan dalam menyampaikan informasi wisata di kota Tanjung Pinang, dan telah dapat dilihat keberhasilannya, maka pemerintah hendaknya lebih meningkatkan kerjasamanya kepada travel biro. Bentuk kerjasama yang dapat dilakukan dapat berbentuk penyusunan kalender even dan penciptaan daya tarik wisata yang lebih bersifat dinamis sesuai dengan perkembangan minat pasar. Dalam hal ini biro perjalanan lebih memiliki pengalaman lapangan dan bentuk kerjasama praktis dengan travel biro di berbagai daerah. Manfaat yang diperoleh antara lain:

1. Pemerintah dapat lebih menghemat biaya promosi, namun target yang dicapai akan lebih tepat (manfaat efesiensi dan efektivitas).

2. Penyampaian citra pariwisata bersifat positif.

3. Feed back informasi dari biro perjalanan kepada pemerintah lebih bersifat up-date terkait dengan perkembangan minat wisatawan.

Berikut Penulis sajikan tanggapan Staff Dinas Kebudayaan dan Pariwisata terhadap kerjasama dengan travel biro. Bahwa rata-rata staff Dinas Kebudayaan dan Pariwisata menjawab Baik yaitu 3 orang $50 \%$. Kerjasama dengan travel biro sebenrnya memberikan umpan balik yang sangat bagus bagi perkembngan pariwisata di Pulau Penyengat. Travel biro dapat menawarkan paket-paket perjalanan wisata ke Pulau Penyengat kepada para wisatawan sebagai objek wisata religi, sejarah dan budaya. Dengan kerjasama ini tentu akan lebih mendatangkan wisatawan ke Pulau Penyengat karena bagaimanapun travel biro akan lebih pro aktif membawa wisatawan datang.

4. Memperbanyak Iklan tentang Pulau Penyengat

Komponen lainnya di bidang promosi wisata ini adalah memperbanyak brosur atau mengiklankan di media massa tentang tempat dan objek wisata yang menarik dikunjungi di kota Tanjung Pinang khususnya di Pulau Penyengat. Hal ini dilakukan sebagai upaya untuk lebih memperkenalkan tempat dan objek wisata yang layak dikunjungi oleh wisatawan yang datang ke kota ini. Dengan adanya kegiatan promosi wisata melalui brosur dan iklan di media massa maka peningkatan kegiatan promosi wisata akan lebih efisien dan efektif karena mudah didapatkan dan didengar oleh wisatawan sehingga menimbulkan keinginan untuk datang berkunjung ke kota Tanjung Pinang khususnya Pulau Penyengat. Upaya lainnya dari kegiatan promosi ini adalah memperbanyak baleho atau papan iklan di pusat kota dan tempat-tempat tertentu yang ramai dikunjungi. Pemasangan baleho ini merupakan salah satu faktor yang relevan dalam memperkenalkan tempat dan objek wisata sehingga lebih dikenal oleh wisatawan bahwa tanggapan staff Dinas Kebudayaan dan Pariwisata dalam mempromosikan iklan pariwisata Pulau Penyengat menyatakan sangat baik dengan persentase $16,7 \%$, dan yang menyatakan baik sebesar $33,3 \%$. Sedangkan yang menyatakan cukup baik sebesar $50 \%$ atau 3 orang. Pemasangan iklan di media massa dan media elektronik, baleho dan papan iklan dipusat kota dan tempat-tempat keramaian serta di objek wisata lainnya dapat dilakukan sebagai alat promosi untuk menarik wisatawan agar berkunjung ke Pulau Penyengat. Seiring dengan perkembangan teknologi saat ini tidak ada salahnya jika Dinas Kebudayaan dan Pariwisata membuat iklan di media-media social dan di website Dinas secara lebih gencar.

semua ini dilakukan dengan harapan meningkatkan kunjungan wisatawan ke Pulau Penyengat melalui beberapa usaha tersebut dapat di atas diharapkan pengembangan pariwisata yang dilakukan akan lebih mampu menahan wisatawan lebih lama berada di kota Tanjung 
Pinang khusnya Pulau Penyengat. Sehingga akan semakin dapat meningkatkan Pendapatan Asli Daerah (PAD) kota Tanjung Pinang. Selain peningkatan Pendapatan Asli Daerah (PAD), diharapkan juga sebagai penggerak roda perekonomian perdagangan, hiburan, restoran, tranportasi dan lain-lain di Pulau Penyengatsecara khusus dan kota Tanjung Pinang secara umum.

\section{Potensi objek wisata di kawasan Mesjid Raya Pulau Penyengat yang dapat diunggulkan oleh Dinas Kebudayaan dan Pariwisata di Tanjung Pinang}

Banyaknya wisatawan yang berlibur untuk berkunjung di Kepulauan Riau juga sangat membanggakan bagi provinsi yang terletak di pulau Sumatera ini. Banyak tempat menarik dari obyek wisata Indonesia yang ada di provinsi Kepulauan Riau seperti wisata religi, budaya dan sejarah. Pulau Penyengat juga merupakan salah satu obyek wisata di Kepulauan Riau, salah satu objek yang bisa kita lihat adalah Mesjid Raya Pulau Penyengat. Adapun potensi yang di miliki berupa keunikan-keunikan pada Mesjid Raya Pulau Penyengat adalah sebagai berikut :

1. Salah satu mesjid yang menggunakan putih teloh sebagai bahan campuran pada pembangunannya.

2. Mesjid pertama yang menggunakan kubah pada atapnya di daerah Kepulauan Riau.

3. Masuknya ajaran agama islam pertama kali di Kepulauan Riau.

4. Mesjid yang tercatat dalam sejarah Indonesia sebagai salah satu peninggalan bersejarah kerajaan Riau-Lingga yang masih ada.

5. Mesjid Raya Pulau Penyngat terdapat 13 kubah dan 4 menara berujung runcing setinggi 19 meter, jika jumlah kubah dan menara menunjukkan bilangan rakaat sholat dalam 1 hari.

6. Didalam Mesjid Raya Pulau Penyengat terdapat buku Tuhfat al-Nafis yang di tulis oleh Raja Ali Haji sebagai pujangga kerajaan Riau-Lingga.

7. Di halaman Mesjid Raya Pulau Penyengat terdapat dua buah rumah sotoh (tempat pertemuan) yang di peruntukkan bagi musafir dan tempat munyawarah, dan ada lagi dua balai tempat untuk menyediakan hidangan ketika kenduri atau untuk berbuka puasa yang di sediakan pengurus Mesjid Raya Pulau Penyengat.

Hal ini dikarenakan Pulau Penyengat tidak hanya menjadi objek wisata religi tetapi juga merupakan objek wisata sejarah. Mesjid Raya Pulau Penyengat saja memiliki keunikan tersendiri yaitu menggunakan putih telor sebagai bahan campuran pembangunan nya terbukti masik kuat hingga saat ini dan menjadi bukti sejarah. Pulau Penyengat sendiri sebenarnya adalah mas kawin yang di berikan Sultan Mahmud kepada Engku Putri Hamida, di saat itulah Pulau Penyengat berkembang dan menjadi Bandar modern yang disinggahi para pelaut dapat beribadah sekligus beristirahat.

\section{PEMBAHASAN}

Mesjid Raya Pulau Penyengat merupakan salah satu andalan dalam mendukung wisata religi dan wisata sejarah kota Tanjung Pinang mengingat banyaknya peninggalan situs sejarah di pulau ini yang bisa menjadi objek unggulan bagi wisatawan domestic dan wisatawan internasional. Dan ada pun upaya promosi yang di lakukan oleh Dinas Kebudayaan dan Pariwisata dalam meningkatkan jumlah kunjungan seperti : tersedianya pusat informasi pariwisata, diadakannya festival pulau penyengat, diadakan kerjasama dengan travel biro dan memperbanyak iklan tentang pulau penyengat. Dan keberadaan Dinas Kebudayaan dan 
Pariwisata saat ini dapat di katakan baik. Dengan berbagai promosi yang dilakukan oleh Dinas terkait sehingga kedepan dapat meningkatkan kunjungan.

Hal ini sejalan pendapat R. S. Damardjati (2001:12) yang mempunyai Badan Promosi Pariwisata Indonesia (BPPI) adalah organisasi non pemerintah yang bertujuan untuk meningkatkan promosi pariwisata Indonesia di luar negeri. Para petugas BPPI ini rata-rata terdiri penguasa/pengusaha swasta yang bergerak dibidang pariwisata ataupun produk-produk jasa lain yang secara langsung maupun tidak langsung. Banyak pengertian tentang promosi yang dikemukakan oleh para ahli keanekaragaman tentang rumusan promosi tersebut antara lain, menurut Philip Kotler (2001:74) yang mendefenisikan promosi sebagai kreatifitas mengkomunikasikan keunggulan produk serta membujuk pelanggan sasaran untuk membelinya.

Potensi wisata yang berkembang di Pulau Penyengat saat ini adalah wisata religi dan wisata sejarah dan budaya. Potensi objek wisata di kawasan Mesjid Raya Pulau Penyengat yang memeliki keunikan adalah antara lain : bahan pembangunannya yang di campur dengan putih telur, salah satu peninggalan kerajaan Riau- Lingga yang masih ada, sejarah masuknya agama islam pertama kali ke kepulauan riau dan dengan 13 kubah dan 4 menara yang ada di Mesjid Raya Pulau Penyengat jika dijumlahkan menunjukkan bilangan rakaat shalat dalam satu hari. Dan disekitar Mesjid Raya juga terdapat komplek makam-makam raja dan makam Engku Putri Hamidah sebagai pemilik Pulau Penyengat. Obyek-obyek wisata ini menjadi favorit kunjungan para wisatawan domestik dan wisatawan internasional.

\section{SIMPULAN}

Upaya promosi yang di lakukan oleh Dinas Kebudayaan dan Pariwisata dalam meningkatkan jumlah kunjungan seperti : tersedianya pusat informasi pariwisata, diadakannya festival pulau penyengat, diadakan kerjasama dengan travel biro dan memperbanyak iklan tentang pulau penyengat. Dan keberadaan Dinas Kebudayaan dan Pariwisata saat ini dapat di katakan baik. Dengan berbagai promosi yang dilakukan oleh Dinas terkait sehingga kedepan dapat meningkatkan kunjungan. Potensi wisata yang berkembang di Pulau Penyengat saat ini adalah wisata religi dan wisata sejarah dan budaya

\section{DAFTAR PUSTAKA}

Basu Swastha, 1995, Asas-Asas Pemasaran, PT. Pustaka LP3ES, Jakarta.

Basu Swastha, 2002, Manajemen Pemasaran. Edisi Kedua. Cetakan Kedelapan. Jakarta: Penerbit Liberty

Happy Marpaung, 2002, Pengantar Pariwisata. Bandung : Alfabeta.

Himawan Kartajaya, 2009, New Wave Marketing. Jakarta: Gramedia Pustaka

Oka A. Yoeti, 2006, Perencanaan dan Pengembangan Pariwisata. Jakarta

Philip Kotler, 2000, Riset Pemasaran dan Perilaku Konsumen. PT. Gramedia.Pustaka Utama; Jakarta 
Philip Kotler, 2001, Manajemen Pemasaran : Analisis, Perencanaan, Implementasi, dan. Kontrol. Jakarta : PT. Prehallindo.

R. S. Damardjati, 2001, Istilah-istilah Dunia Pariwisata. Jakarta

Salah Wahab, 1992, Manajemen Pariwisata. Angkasa, Bandung 